bikinis and other s/pacific n/oceans

Teresia K. Teaiwa

\title{
Specific Notions
}

What does the word bikini evoke for you? A woman in a two-piece bathing suit, or a site for nuclear-weapons testing? A bikini-clad woman invigorated by solar radiation, or Bikini Islanders cancer-ridden from nuclear radiation? The sensational bathing suit was named for Bikini Atoll. This was the site in the Marshall Islands for the testing of twentyfive nuclear bombs between 1946 and 1958 . Bikini Islanders testify to the continuing history of colonialism and ecological racism in the Pacific basin. The bikini bathing suit is testament to the recurring tourist trivialization of Pacific Islanders' experience and existence. By drawing attention to a sexualized and supposedly depoliticized female body, the bikini distracts from the colonial and highly political origins of its name. The sexist dynamic the bikini performs-objectification through excessive visibility-inverts the colonial dynamics that have occurred during nuclear testing in the Pacific, objectification by rendering invisible. The bikini bathing suit manifests both a celebration and a forgetting of the nuclear power that strategically and materially marginalizes and erases the living history of Pacific Islanders. The bikini emerges from colonial notions that marginalize "s/pacific" bodies while genericizing and centering female bodies.

For Pacific Islanders the name Bikini evokes memories and visions of a s/pacific historical and contemporary political reality. Nuclear testing is just one-albeit a most pernicious one-of the many colonial phenomena and processes that affect the Pacific region. In I980 the United Nations reported that more than 200 nuclear bombs and devices had been detonated in the Pacific, but this figure did not include nuclear missiles

The Contemporary Pacific, Volume 6, Number I, Spring 1994, 87-109

(C) 1994 by University of Hawai'i Press 
launched into the Pacific by the United States, the Soviet Union, and China (Firth $1987, \mathrm{ix}$ ). Britain exploded 12 nuclear bombs on Johnston Atoll between 1958 and 1962, and in the 1950s conducted I2 tests at Monte Bello, Emu, and Maralinga in Australia. Since 1966 France has tested 4I atmospheric bombs and continues to test underground at Moruroa and Fangataufa (Siwatibau and Williams 1982).

The New World Times reported tests at Moruroa in June and November of 1990 , bringing to I30 the total of underground tests there since 1975 . The New World Times also reported Professor M. Hochstein, director of Auckland University's Geothermal Institute, as saying that the shafts at Moruroa may contain about a hundred times the amount of radioactive material dropped on Hiroshima (NWT 1990). Nuclear testing in Australia and French Polynesia profoundly affects the health and welfare of indigenous peoples. In April 1992 France announced a twelve-month suspension of its nuclear tests in the Pacific, with the possibility of extension if other countries join in a moratorium (SJMN 1992). Although both the United States and France declared at the August 1993 South Pacific Forum meeting in Nauru that they would cease testing in the Pacific, their nuclearpowered (and armed) vessels continue to "patrol" the ocean. Current global political realignments-the dissolution of the Soviet Union and the development of nuclear capabilities by Third World nations-have complicated the configuration of both the nuclear arms race and the antinuclear movement. The Pacific Ocean, however, still churns with its colonial and nuclear legacies. Bikini epitomizes these legacies.

\section{BIKINI}

On a Euro-American map, Bikini Atoll is located at 165 degrees east of Greenwich or 15 degrees west of the international dateline, between latitudes Io and 20 degrees north of the equator. The atoll surrounds a lagoon some 40 kilometers long and 20 kilometers wide, and is composed of twenty-six islands-Bikini being the largest-covering a surface area of 7 square kilometers. Bikini Atoll is part of the Republic of the Marshall Islands, former colony of Germany, Japan, and the United States of America. The republic is currently politically linked in "free association" with the United States (Johnson I988).

The Marshall Islands became a part of the US Trust Territory of the Pacific as a result of Japan's defeat in World War II. The most horrific 
component of US military strategy during the war was the nuclear bombings of Japan at Hiroshima and Nagasaki on 6 and 9 August 1945. Within the subsequent context of a cold war with the Soviet Union, the United States proceeded to further test and develop its nuclear and naval powers on and around the Pacific islands entrusted to it by the United Nations (Firth 1987).

The United States decided to test at Bikini for several strategic reasons. The area was under its control; the islands were in a climatic zone free of storms and cold temperatures; the lagoon was large enough for a fleet of target vessels; the population of Bikini in I946 was between I66 and I70 people-small enough to be relocated with relative ease; and ultimately, Bikini-and the Marshall Islands in general-were at least five hundred miles from all sea and air routes, distant enough that ensuing radioactive contamination would not endanger "heavily populated areas" (Kiste 1974, 27).

The US military secured the cooperation of the Bikinians in vacating their island by appealing to their sense of Christian duty. ${ }^{1}$ On ro February I946 the Islanders were told by the military governor that Bikini would be used for "the good of mankind and to end all world wars" (Kiste r974, 28). By 7 March 1946, after repeatedly reenacting for camera crews their "consultation" with the military governor, the Islanders departed for the temporary home of their choice on another atoll, Rongerik, just over a hundred miles east of Bikini (see map). The nuclear project, code-named Operation Crossroads, could then be implemented. Some forty-two thousand US military personnel-twenty of whom were women-were on hand for the two tests conducted on I July and 25 July (Stone 1988). ${ }^{2}$ The US military went on to conduct other nuclear tests on Enewetak Atoll, and to establish a support base on Kwajalein. During this period, the people of these atolls, and others like Rongelap and Utirik, were subject to radiation, displacement, or both (Johnson 1988 ).

Since 1946 the Bikini Islanders have experienced the many troubles attendant on relocation-or dislocation. Within a year Rongerik proved inappropriate because its lagoon and plant life could not support the Bikinian population. The move to Rongerik had also placed the Bikinians under the jurisdiction of a paramount chief, a fact that did not please them. Subsequently the Islanders were sheltered at the military base on Kwajalein Island. In 1948 they were moved to Kili Island, and in the I950s the US government awarded them $\$ 25,000$ in cash plus a $\$ 300,000$ trust 


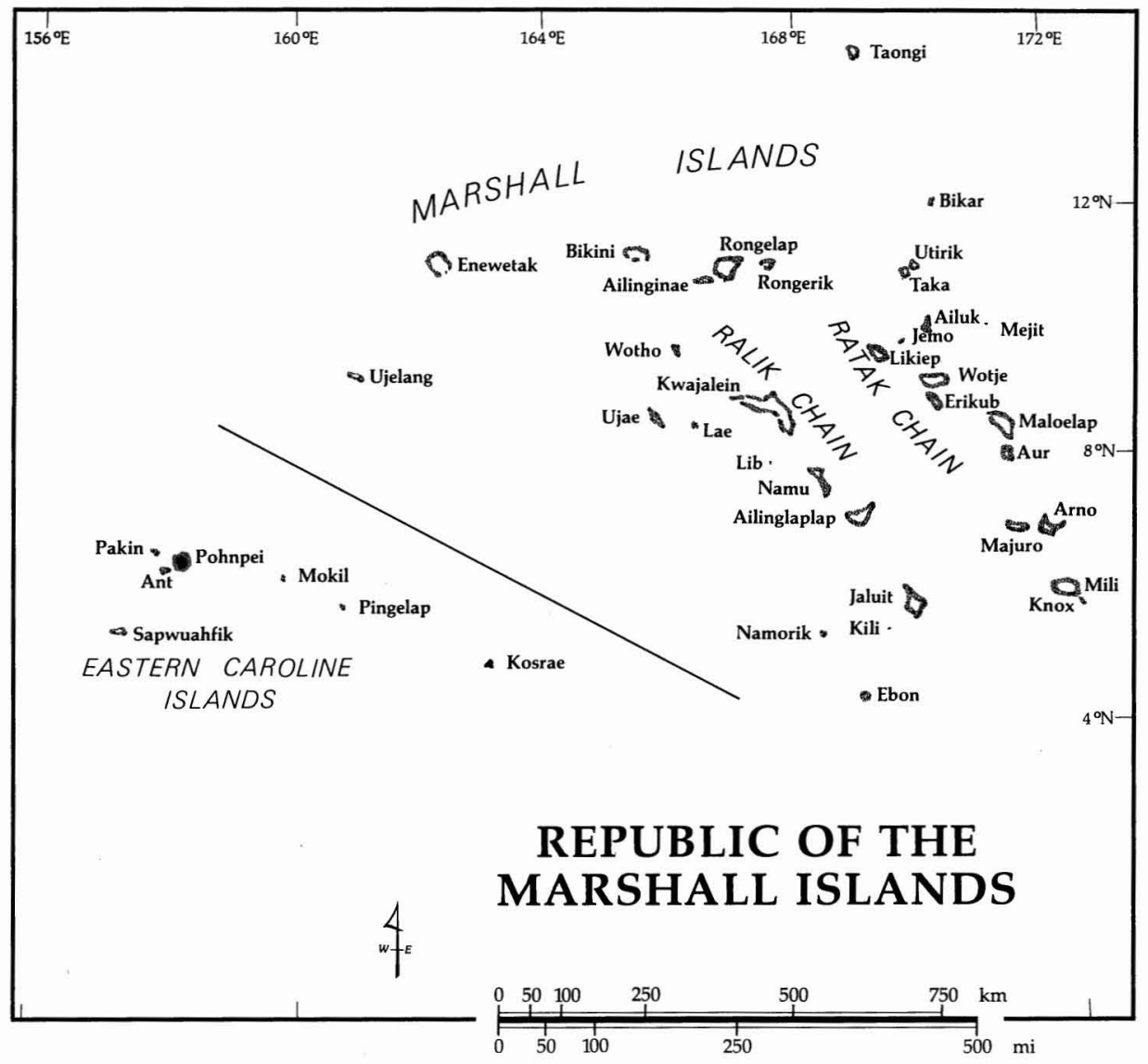

fund for full use in their homeland. This monetary compensation provided some relief, but eventually the Bikinians faced more population pressures on Kili as their numbers grew to three hundred by 1970 (Firth 1987). Furthermore, their desire to return to Bikini was still strong, for they had a specific physical and spiritual relationship to their homeland that the colonial government could not fully appreciate. ${ }^{3}$

In 1968, after the Atomic Energy Commission declared the island safe, US President Lyndon B. Johnson assured the Bikinians that they would be repatriated soon. At least one hundred Bikinians returned, but the island was still dangerously radioactive, because of the twenty-three nuclear tests conducted there between 1946 and 1958; it would take a minimum of thirty to sixty years for some areas to be safe again (MSC 1978). When the United States finally admitted that the island was still unsafe, the Islanders were forcibly evacuated again in 1978 . 
At this time Bikini Islanders are scattered throughout the Marshall Islands, with most living on Kili, Kwajalein, or Majuro (Firth 1987). Numerous claims had been filed against the United States as the Islanders became afflicted with radioactivity-related cancers and birth defects. A radically altered version of the Compact of Free Association between the Republic of the Marshall Islands and the United States, approved by the US Congress in 1986, allocated a \$150-million trust fund for nuclear victims from four atolls-Bikini, Enewetak, Rongelap, and Utirik-exposed to radiation during the period of testing (Johnson 1988). Bikinians subsequently filed a $\$ 450$-million lawsuit against the United States, to which the US Congress responded in 1988 by approving a \$90-million trust fund for cleaning up and resettling Bikini (Johnson r992). Although the Bikinians may attempt to take the US government to court again, it is not likely they will achieve much more than this. The Bikini Islanders' resettlements have been troubled by environmental, social, economic, political, physical health, and emotional considerations.

\section{BIKINIS}

In 1946 French designer Louis Reard launched a sensational two-piece bathing suit (Donald 1985). The bikini, as it was christened, celebrated the Allied efforts in World War II. Fashion historians have noted that European vogues in revealing clothing tend to coincide with periods of war.

Fashion is always at its most provocative during or after times of war, for the excellent reason that, from the woman's point of view, there is more than a good chance of a lot of eligible males turning up their toes at any minute (one night at the Duchess of Richmond's Ball, the next day carnage at Waterloo) so speed is of the essence in the sexual come-on message. (Glynn 1982, 96) ${ }^{4}$

Clothing and fashion, of course, can be manipulated by both individuals and society. An individual woman may choose to expose her body for attention, but society also has investments in such display. In the context of war, society has an ideological stake in the reification of female bodies when male bodies are being sacrificed heroically.

During the First World War women were urged to inspire and distract the boys as they marched off to battle or came home on leave. A new coquettishness began to affect female swimwear as daring exposures overtook everyday dress and corsets were abandoned. Collar-bones and elbows, ankles and calves came into view on the street, and evening dresses, suspended by the thinnest straps 
bared even the armpit. On the beach, instead of fending off masculine attention with massive yardage, it now became entirely respectable, even a tinge patriotic, to begin cautiously to gratify the searching male gaze. (Hollander 1990, 58 , emphasis added)

The bikini bathing suit found its position in this fashion ideology. While being liberated from earlier cumbersome swimsuits, bikini-clad women ${ }^{5}$ joined other variously clothed-or unclothed-model female images pinned up for a heterosexual male gaze.

[A] system of power . . . authorizes certain representations while blocking, prohibiting or invalidating others. Among those prohibited from Western representation, those representations denied legitimacy, are women. Excluded from representation by its very structure, they return within it as a figure fora representation of-the unrepresentable (Nature, Truth, the Sublime, etc). Yet in being represented by, women have been rendered an absence within the dominant culture. (Owens 1983, 59)

The mass production and distribution of seminude female images are forms of sacrifice-or symbolic atonement-that substitute and domesticate the unrepresentable chaos of nuclear war.

$[\mathrm{T}]$ he original scientists working at Los Alamos took bets among themselves as to whether they would ultimately have a "boy" or a "girl," that is, a success or a dud. A success it was, and the "fathered" (by J. Robert Oppenheimer) bomb was nicknamed "Little Boy." A few years later, the bomb underwent a sex change operation: the device dropped on the Bikini Islands was nicknamed "Gilda" and painted with an image of sex symbol Rita Hayworth." (Caputi I99I, 426)

The sacrifice of Islanders and military personnel during nuclear testing in the Pacific cannot be represented without threatening the legitimacy of colonial power, so nuclear technology becomes gendered and domesticated. In the end the female body is appropriated by a colonial discourse to successfully disguise the horror of the bomb.

Edward Said describes such a colonial discourse as positioning "the West" as actor as well as spectator, and "the Orient" (or, for our purposes, the exotic) as passive reactor or malleable site (Said 1978). ${ }^{6}$ In this sense the bikini offers a female body as affirmation of a colonial gaze. The bikini politically negates the female body by exposing it, but by its mass exposure in the bikini the female body also negates the history of $s /$ pacific 
bodies. ${ }^{7}$ The bikini-clad woman is exotic and malleable to the same colonial gaze which coded Bikini Atoll and its Islanders as exotic, malleable and, most of all, dispensible.

The bikini is, in effect, more about European and American sex-gender cultural history than about Pacific Islanders. But the bikini's seminudity also reflects a conjunction between conceptions of the neoclassical and the South Sea noble savage that began in eighteenth-century European imagination. After his 1768 voyage, French explorer Bougainville explicitly compared the Tahitians with ancient Greeks:

"I never saw men better made, and whose limbs were more proportionate: in order to paint a Hercules or a Mars, one could nowhere find such beautiful models." A naked young Tahitian girl on the deck of his ship appeared, "as Venus ... . herself to the Phrygian shepherd having the celestial form of that goddess." (Smith 1960, 25)

Eighteenth-century artistic representations of Venus were lent validity by documentations of European encounters with scantily clad South Sea Islanders. When early bikini-clad women were hailed as "Venuses," the bikini's genealogy seemed noble.

The most simple way for society to get away with practically anything, or practically nothing, was to pretend that their fashions were inspired by some great bygone age. Thus when confronted with accusations of indecency they could pretend an innocent hauteur towards anyone who complained. . . . the most extraordinary displays of flesh have been permitted under the justification that they were "classically inspired." (Glynn 1982,96 )

The bikini exoticized generic female bodies by constructing them as references to a Grecian Golden Age and a South Sea Paradise; in this genealogy the more immediate colonial and nuclear ancestry was conveniently marginalized. (By "generic female body" I mean a body that emphasizes femaleness and implies heterosexuality over and above any other specificity of social identity.) As a result of emphasizing continuity between the Euro-American past and the Pacific Island present, this genealogical construction masked the ruptures caused by their convergence.

If at its birth the bikini offered white bodies the opportunity to become tanned, colored, or otherwise marked as exotic, bikini-clad bodies have subsequently become "natural" props in a scene of leisure. American media representations of the bikini, like Entertainment Tonight's bikini 
specials, emphasize the desirability of an idealized female body. ${ }^{8}$ While some women in the United States have recognized that the representation of women in bikini bathing suits undermines their efforts at redressing sexism, ${ }^{9}$ the sinister implications of the bikini go beyond sexism. The bikini's deep structural symbolism is significantly repressed in its popular manifestations. ${ }^{10}$

The appropriation of the name Bikini, a s/pacific site of trauma and dispossession, for a sexy generic bathing suit functions as fetishism. By using the fetish as a theoretical framework I do not intend disrespect to those objects Westerners have labeled fetishes or those that have embedded sacred meaning for indigenous peoples. I intend rather to critique the type of fetishization that objectifies and vulgarizes otherwise meaningful subjects. Several critics have warned of the remystifying abilities and the dangers of making a fetish out of the concept of fetishism (Apter 1991). Nevertheless, this paper mobilizes a concept such as the "fetish" to describe a(nti)historical and sexist elements of European and American cultural constructions and political processes in the Pacific.

In Civilization and Its Discontents, Sigmund Freud discussed a process by which the fetish stopped the memory in traumatic amnesia: the fetish is a conceptual substitute for a penis (for Freud, the mother's) "which should normally have been given up, but . . . is precisely designed to preserve it from extinction. ... [The fetish] remains a token of triumph over the threat of castration and a protection against it" (Freud 1961, I53-I55). I take nuclear weapons as the ultimate phallic and castrative symbols for specific national cultures within a global political context. ${ }^{11}$ The bikini bathing suit functions as a token of triumph (a fetish for Western Europe and the United States) over the threat of castration by enemy nations, and as psychic protection against the horror of their own destructive powers.

The simultaneously reified and repressed multiple symbolisms of the bikini-as-fetish resonate with aspects of Julia Kristeva's psychoanalytic framework. Kristeva discussed woman's position as "both 'inside' and 'outside' male society, both a romantically idealized member of it and a victimized outcast. She is sometimes what stands between man and chaos, and sometimes the embodiment of chaos itself" (Eagleton 1983, 190). Through assumptions of its significance on a generic female body, the bikini represents sex-gender ideologies produced in Western Europe and the United States. A bikini-clad woman visually embodies and denies both sexual and nuclear chaos. 
As Freud maintained, there is "an aversion, which is never absent in any fetishist, to the real female genitals" (Freud 196I, I54). The bikini exposes everything but the breasts and the pubic area. While the breasts are tantalizingly emphasized, pubic hair is considered fashionably deadly if not concealed: women are encouraged to shave or wax their bikini lines. The fetishistic aversion to real female genitals extends to female body hairsolidifying the relationship between the bikini-clad woman and the classical female nude, which is never portrayed with pubic hair. The classical fetishization of the female body converges with contemporary fetishization of the bikini-clad body.

As a commodity, the bikini exceeds its material utility and begins to mediate social-that is, gender and colonial-relationships (Marx 1962). ${ }^{12}$ Although a traditional Marxist analysis would focus on the commodity's evolution from product of human labor to "idol of the marketplace," I am more interested in the process that alienates the colonized referent of the commodity. To this end I find a discussion by Emily Apter particularly illuminating. She comments on literary representations of the commodification of exotic others in a French fin-de-siècle novel, La Goutte d'or. Idriss, a Maghrebian man, sells a polyethylene cast of himself to a Parisian department store and is subsequently recruited as a model to stand in the store window performing a few angular and spasmodic gestures to promote the sale of the casts:

In the mirror reflection of a thousand, identical department-store mannequins, one can extract a political critique of the alienated, colonized, North African self. In this sense, fetishism "buys back" its political redemption. Though Idriss may be prostituted, frozen, and reified, his dead stare (Medusa's head) gives back to consumer society the very alienation that consumer society has inflicted on him. (Apter I99I, I2)

The relationship between the commodity (the mannequin) and its colonized referent (Idriss) in this case is direct; the bikini on the other hand has two colonized referents, and privileges (however minimally) one (generic South Sea noble savage) over the other (dispossessed Bikinians). The mass-produced-and-marketed bikini simultaneously transcribes and erases the dispossession of the Bikini Islanders onto millions of female bodies. Although Apter sees some redemption in such a paradox, the emptiness of commodity consumption is only benign if we ignore the malign effects of the bikini's co-commodity, the bomb. 


\section{Toward Nuclear-Free and Independent S/Pacific Bodies}

The bomb and the bikini are colonial military and neocolonial tourist technologies respectively, and as such have a profound impact on s/pacific bodies. I would like to take some time here to explain my notion of the s/pacific body. Barbara Christian criticized French feminist theorists's position of the body as the generating source of knowledge because they "return to the old myth that biology determines everything and ignore the fact that gender is a social rather than a biological construct" (Christian I987, 233). I agree with Christian insofar as constructions of biological inferiority have legitimized the historical oppression of many people. I hold, however, that the body is the site of physical and social experience, and as such cannot be denied the potential for generating liberative knowledge. For, as Elizabeth Spellman has noted, somatophobia, or fear and disdain of the body in Western thought, has been associated historically with intellectual superiority (Spellman 1988). The s/pacific body emerges for me as a site for comprehending specific social and physical environments and for apprehending generic colonial technologies of marginalization and erasure.

The decolonization of s/pacific bodies is intimately woven into island women's activism. ${ }^{13}$ Women have been in the vanguard of many Pacific Island sovereignty movements. Perhaps most exemplary of women-initiated decolonization in the Pacific is the group of Belauan women, Otil a Beluad, who have consistently organized resistance to US and domestic pressures to amend the antinuclear constitution of Belau (Teaiwa 1992; Weera 199I). The nuclear presence in the Pacific, however, is only one symptom of the everyday multiplicity of (neo)colonial onslaughts on s/pacific bodies. Pacific Island women also organize around issues of health, environment, substance abuse, and domestic violence for the sovereignty of s/pacific bodies. Activist efforts counter colonial notions that attempt to marginalize and erase them: the romantic notion of a nude South Sea Islander and the militaristic notion of islands as expendable spaces for nuclear testing.

Because nudity and nuclear testing both take on moral and ethical dimensions, Christianity - the most overtly popular religion in the Pacific -figures prominently in any discussion of both the colonization and the decolonization of s/pacific bodies. If we remember that the Bikinians surrendered their island out of Christian charity, we must also acknowledge 
that Christian organizations of predominantly indigenous women are instrumental in the Nuclear Free and Independent Pacific movement. ${ }^{14}$ Christianity's role in the Pacific has certainly been ambiguous. ${ }^{15}$

Early encounters between men (and women) of the cloth and naked natives were marked by violence. ${ }^{16}$ By the late eighteenth century, European Christians had determined that the islands were purgatorial rather than paradisical, and that the noble savage was really ignoble: Islanders needed both salvation and civilization, and mostly they needed to be clothed (Smith 1960). ${ }^{17}$ The missionaries swathed s/pacific bodies in cotton laplaps, mother hubbards, and short trousers. Clothing functioned as a device of colonial social control, not only by eliminating nudity, but in colonial Papua, for instance, by distinguishing appropriate dress for Islanders from appropriate dress for Europeans (Woolford I974, 9-10). ${ }^{18}$

As tourism has become a primary industry for many of the postcolonial Pacific Island nations, Islanders are increasingly exposed to sun-seeking and seminude "First-Worlders." In general, Islanders are wryly amused by contemporary Euro-Americans' various states of undress:
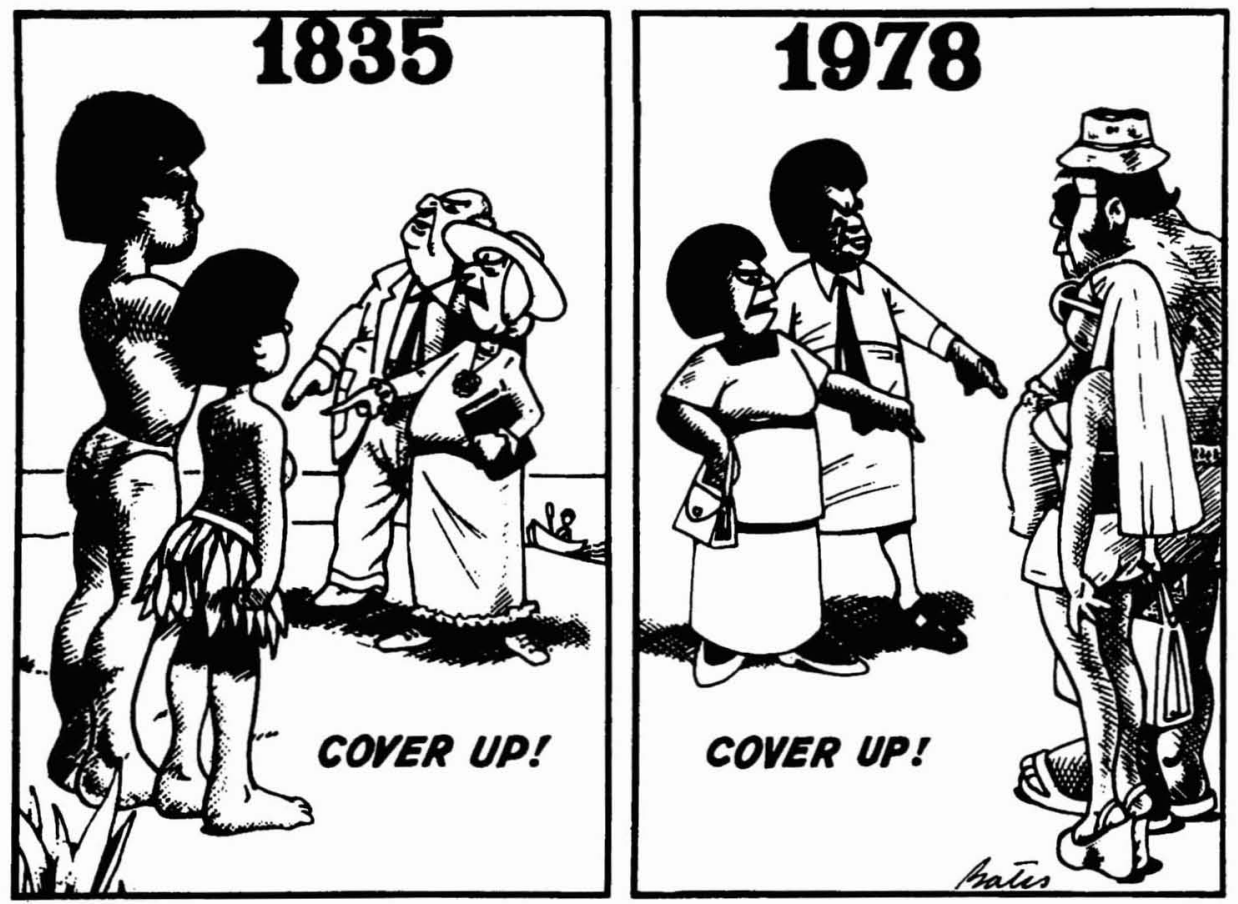

FIGURE I. Modesty then and now as seen by editorial cartoonist Bill Bates. (Courtesy of Fiji Sun) 
It's an irony that the white man who came to us puritanically stiff and overdressed, now wears hardly anything on the beach on a summer day or on a Sunday afternoon. He has even gone further than that: he now streaks through the streets or the parks in America or Europe, and some countries plan to set aside certain areas and beaches for nudists only. . . . So who is playing naked now? I hope we have taught the white man a lesson in innocence and healthy living! (Aiavao $1985,8-9$ )

Most Islanders, influenced by Christian modesty, wear "bathing suits" that are considerably more voluminous than the bikini. The lavalava, or pareo, or shorts and a T-shirt, or even a dress (for women), rather than the bikini are the most common attire for Islanders at the beach.

In a tourist economy, the beach becomes the principle site of leisureand a clichéd backdrop for bikini-clad tourists. Of course, tourism also affects Islanders' perceptions of themselves and their environment, and increasing numbers of upwardly mobile Islanders-especially in Fiji, Hawai' $i$, and Tahiti-may be seen lounging leisurely on the beach in their bikinis. There is a bitter irony in this transformation of the beach and the

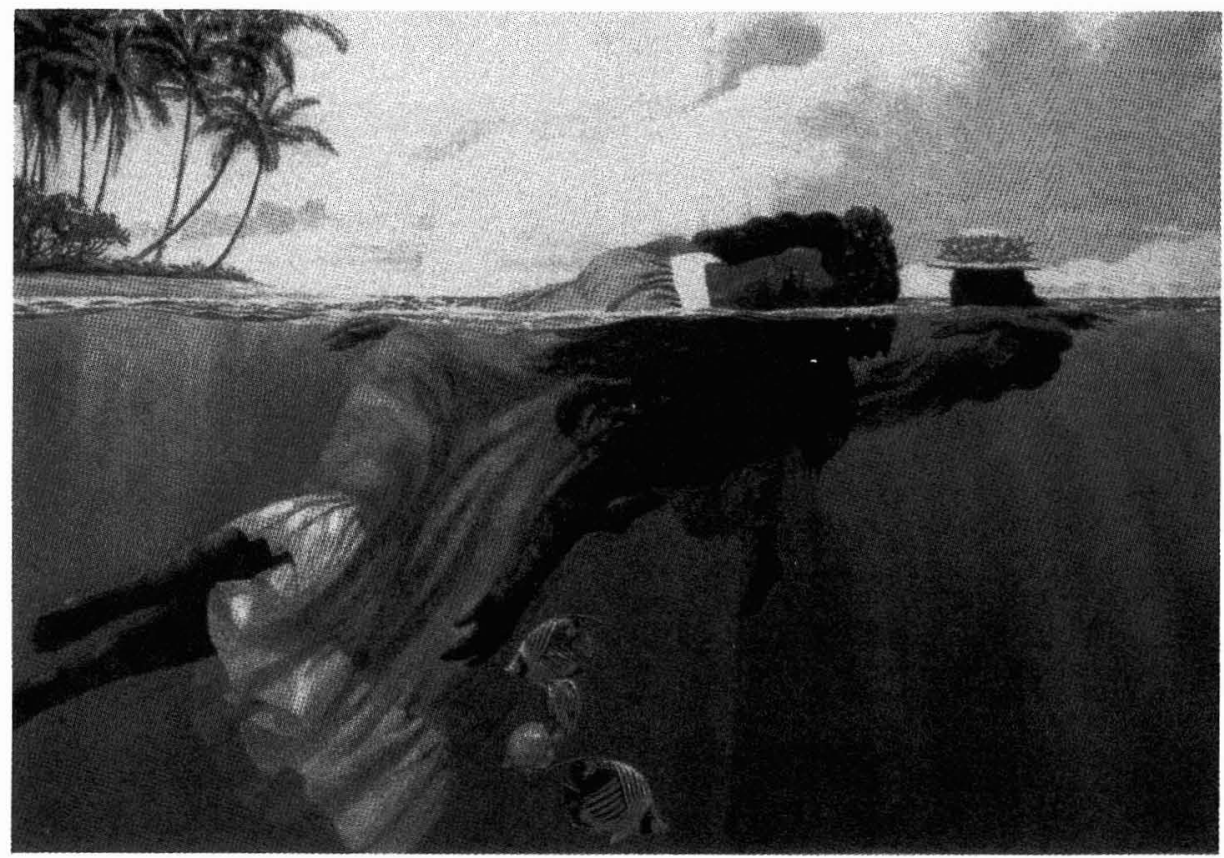

FIGURE 2. Daughters of the Sea, a painting by Herb Kawainui Kane. (C) Herb Kawainui Kane; reproduced with permission) 


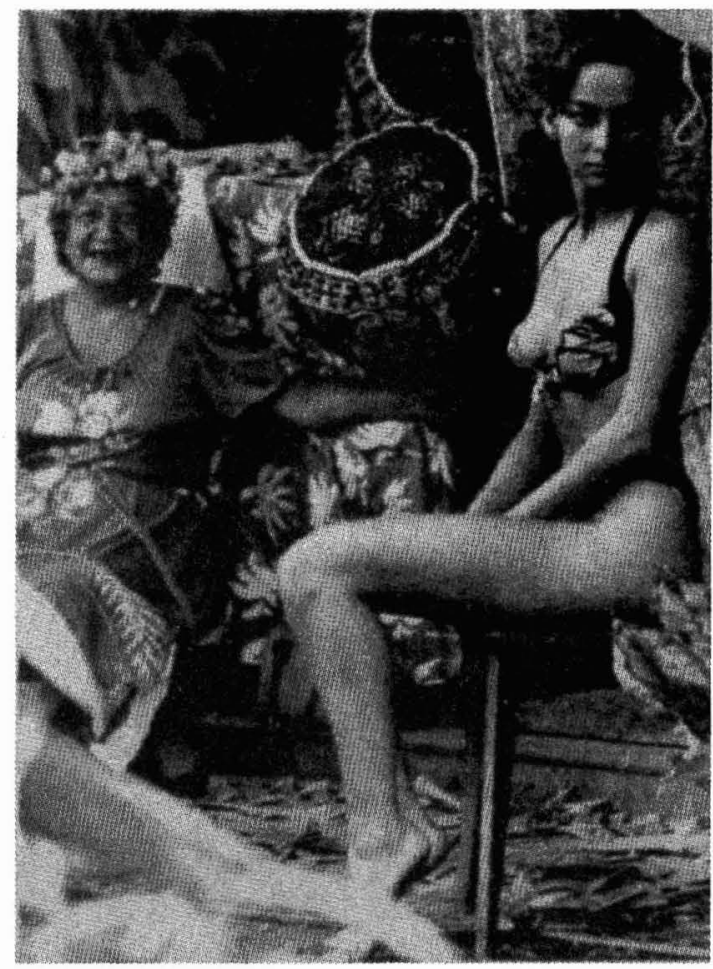

FIGURE 3. Tahiti look, Pape'ete, 1988. (Courtesy of Islands Business)

production of the bikini, for in Marshallese "bikini" means beach, and for the Bikini Islanders the beach was the space they crossed to surrender their island for the nuclear tests of the United States. ${ }^{19}$

Organized protest against nuclear testing in the Pacific began in 1970 when the committee Against Tests on Moruroa (Атом) was formed in Suva, Fiji. Its membership came from the Pacific Theological College, the University of the South Pacific, and the Fiji YwCA. When Aтом organized the first Nuclear Free Pacific conference in Suva in 1975, the Pacific Conference of Churches was its principal cosponsor.

The movement for a Nuclear Free and Independent Pacific (NFIP) gained momentum with subsequent conferences in various island states: Pohnpei in 1978, Hawai' $i$ in 1980, and Vanuatu in 1983 (Firth, 1987, 133), the most recent being held in Suva in I991. A loosely organized information and lobbying network, NFIP encompasses trade unions, private aid 


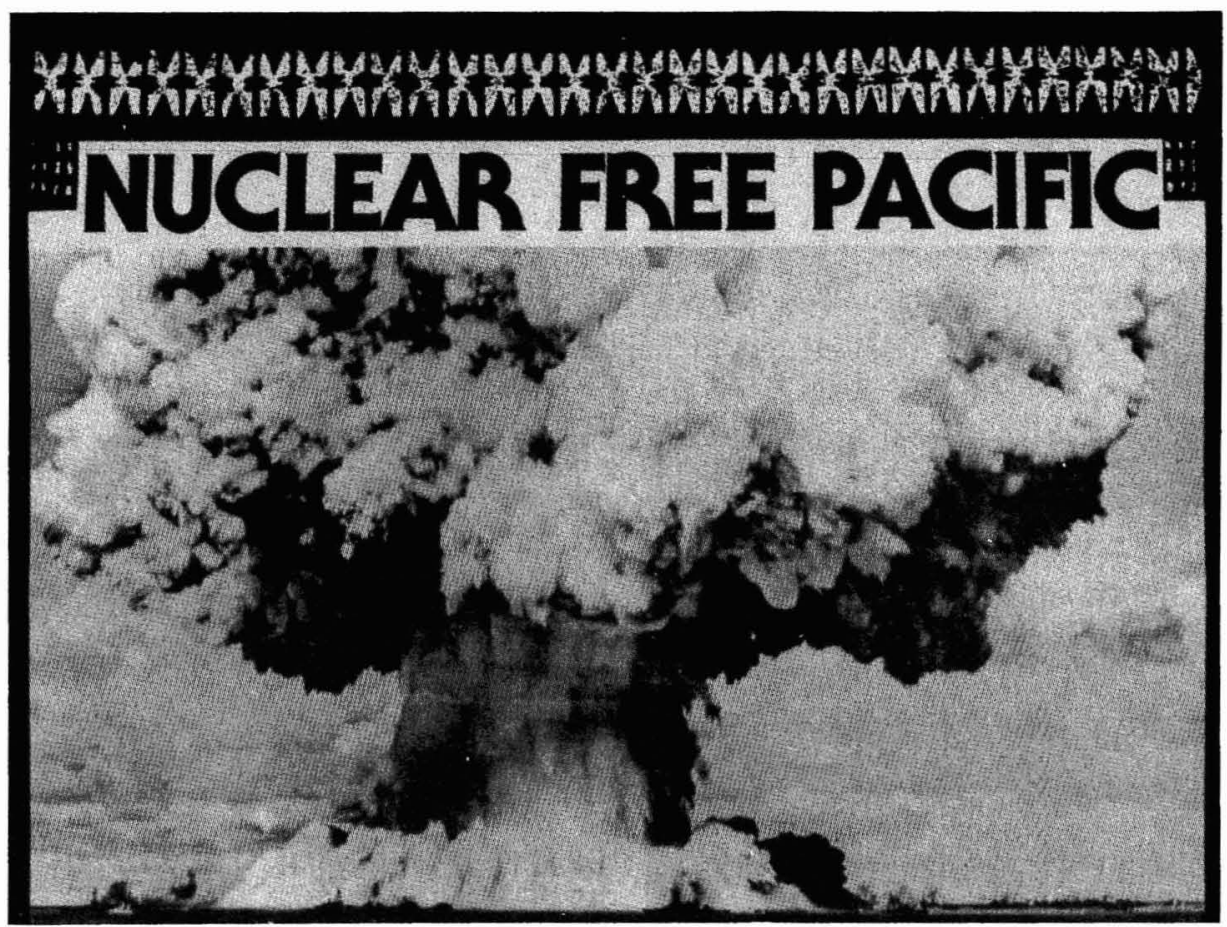

FIGURE 4. From a Nuclear Free and Independent Pacific poster, 1980.

organizations, environmentalists, disarmament lobbies, women's collectives, and Christian groups (Firth 1987). Australian scholar Stewart Firth described its successes in his book Nuclear Playground:

Its lobbying has helped dissuade the Japanese, so far, from dumping radioactive waste in the deep ocean trenches off the Northern Mariana Islands in the northern Pacific; and because of the movement's complaints, the military forces of Australia and Japan no longer bombard the island of Kaho'olawe during annual exercises with the Americans, in deference to the cultural significance of the island to native Hawaiians. Who would have predicted in 1980 that within six years the independent countries of the South Pacific would be seeking to establish a nuclear free zone? Or that the ANZus Treaty would be in abeyance because the New Zealanders refused to be defended by nuclear weapons? Or that the forces in favour of the nuclear free constitution in Belau would have resisted the USA for so long? (Firth 1987, 134)

NFIP has adopted a radical platform that advocates independence and sovereignty movements in the Pacific. These include supporting the Kanak 
independence struggle in the French colony of New Caledonia and opposing the Indonesian government's policy of transmigration and genocide in its colony, West Papua (Firth 1987). ${ }^{20}$

NFIP operates on the premise that whatever happens in one part of the Pacific Ocean affects the whole ocean, the continentals living on the edge of it, and the Islanders living in the midst of it. ${ }^{21}$ Since the nuclear specter first appeared in the Pacific-Hiroshima and Nagasaki in 1945 and Bikini in 1946 -it has spread its poison at an alarming rate.

The biggest stumbling block for Pacific Islanders in lobbying internationally is that they constitute a very small portion of the world's population. By 1986 statistics the total population of the Pacific Islands was 4,952,470 (Pacific Magazine Corporation 1986). ${ }^{22}$ The size of Bikini Atoll's population was a significant factor in making it a site for nuclear testing. When addressing the future of the US Trust Territory of the Pacific Islands in 1969, Henry Kissinger made a comment for which he has become notorious in the Pacific: "There are only 90,000 people out there. Who gives a damn?" (Kiste 1974, 198).

It ends up being all about bodies-but vastly different ways of finding meaning in bodies. There are more bikinis being sold globally every summer than there are Bikinians receiving compensation for dislocation and exposure to radioactivity. While practically every slick nightclub in Waikīki holds a weekly bikini contest, the Nuclear Free and Independent Pacific movement organizes annual commemorative and educational events on I March, which is designated Bikini Day.

\section{S/PACIFIC N/OCEANS}

What are we to make of these bizarre juxtapositions? The bomb and the bikini remind us of the militarist and tourist notions that shaped a particular historical moment in the West and continue to shape the contemporary Pacific Islands. At their inception, the bomb and the bikini reflected a supreme ambivalence in Western thought: the valorization of woman as Nature, the abom(b)ination of nature manifested by military and scientific technology, the naturalization of racial difference, and the feminization or domestication of military technology. How else can we explain the influx of images of women as sex symbols, the persistent development of nuclear weapons technology, racist paternalism toward colonies and territories, 
and the psychological domestication of nuclear technology, except as a peculiarity of Western culture and history? More to the point, how are we to deal with this peculiarity? I am tempted to conclude this paper with a simple demand for a moratorium on the production and display of bikini bathing suits to coincide with a moratorium on the production and testing of nuclear weapons. But while I do believe that such a demand is warranted, the more immediate purpose of this particular academic exposition is to develop a critical understanding of cultural artifacts and representations of the Pacific Islands.

Military, economic, racialized, and gendered histories converge in the bikini bathing suit with far-reaching ideological and material implications. In this paper I have attempted to explore and elucidate some of these implications by selectively applying Marxist, psychoanalytic, and feminist theories. Marxism and Freudian psychoanalysis are particularly illuminating lenses through which to view commodities or fetishes like the bomb and the bikini. Feminist approaches provide a crucial critique of the gendered social relations, representations, and audience reception that surround the bikini's particular history. But although they may effectively describe processes of violence and commodification, largely Eurocentric theories must remain ornamental to narratives that interrupt dominant historical and cultural constructions of islands as military bases and tourist sites.

Faced with a thesis as disturbing as the bomb and the bikini's erasure of specific (Bikini) Islander history, I have had to acknowledge both destructive and life-sustaining histories. The Bikinians and other Marshallese Islanders are at a distinct disadvantage in negotiating terms with the government of the United States of America. Remembering and rearticulating the history of Bikinians' forced migration and exile is a beginning form of resistance to the ideology that created both the bomb and the bikini. I believe that the hope for most specific Islanders is in collective resistance to military and tourist encroachments; this is why I have retold a history of the Nuclear Free and Independent Pacific movement. With its commitment to indigenous rights and support from and for women's organizations, the movement embodies a history that radically challenges military and especially tourist notions of the island Pacific's significance. NFIP's history is informed by what I call "s/pacific n/oceans"-an explicitly politicized version of what some call the Pacific Way. S/pacific n/oceans honor the specificities of Islander experience, recognize the generic effects 
of (neo)colonialism on all Islanders, and are committed to political and cultural cooperation at the regional level. Together the histories of specific islands and s/pacific n/oceans surround cultural artifacts and representations of the Pacific, and erode the generic constructions on which both military and tourist industries depend.

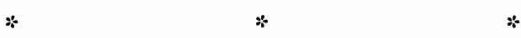

A VERSION of this paper was presented at the ninth Pacific History Association Conference in Christchurch, New Zealand in December 1992.

Thanks to Professor David Hanlon of the University of Hawai' i for constantly encouraging my intellectual growth and risk-taking; from the board of History of Consciousness, Professor Angela Y. Davis for guiding me through this paper from its inception, Professor Barbara Epstein for expanding my understanding of military culture and history; Elena Tajima Creef, Laura Hyun-Yi Kang, Megumi Kitahara, and Sean Tavizonee-Salas for providing critical feedback and collegial support as I developed my theoretical approach to this work. Mahalo nui to J. Kehaulani Kauanui for inspiring me with her own work and providing me with a forum at UC Berkeley where I presented the first draft of this paper. My appreciation to Charles H. Martin for sharing his insight with me on the significance of destructive and life-sustaining histories. Other family members, friends, and colleagues have made much relevant nuclear-testing/bikini-related information available to me, for which I am always grateful. Any and all problems remaining in this article, however, are my responsibility.

\section{Notes}

I Bikinians' first encountered Christian missionaries in 1908 (Kiste 1974, I8).

2 John Stone, Radio Bikini: The US forces observed the tests from the edges of a twenty-mile perimeter around Ground Zero. The effects of radioactive exposure on the observers have not been acknowledged by the US government. In Stone's film a former naval corps member talks about the life-threatening physical distortions afflicting him since he observed the tests.

3 Laura Hyun-Yi Kang has pointed out that the ease with which the colonial United States dislocated the Bikinians arose out of its genericization of islands"one island is just like another"-and denial of the subjectivity of colonized others (pers comm).

4 Most of Glynn's feminist analysis may seem moralistic and somewhat simplistic, but it has a certain political effectiveness. Other aspects of her discussion 
are more nuanced, for example, her attention to male fashion and fashion's relationship to church and state.

5 When the French first introduced the bikini bathing suit to the United States, models were reportedly uneasy about their tops slipping off, their bottoms hitching up, and their pallid skin being exposed (Life 1949).

6 Incidentally, the South Seas was sometimes conflated with the Orient or "East" by seventeenth-century Europeans. A contemporary reviewer of the pantomime Omai wrote, "This pantomime is founded on an Eastern tale"; he also described a Tahitian marae in the pantomime as a "repository for the bodies of the Eastern kings in Otaheite" (Smith 1960, 93). Such conflations illustrate just how randomly and generically Europeans imagined their exotic "others."

7 John Berger has discussed how a ruling class mystifies history by making art inaccessible to the general populace $(1972$, II). This paper works on a variation of his thesis: when the general populace sees so much of the bikini, history is still mystified.

8 CBS's "Entertainment Tonight" featured a series on the bikini that included stories on people who had made fortunes either by designing and marketing the bikini or by promoting beach bikini contests ( 8 Nov I99I). The "ideal" female bodies displayed in bikinis in this series become generic commodities for the titillation of a male gaze and the enticement of a female consumer.

9 ABC's "A Current Affair" (27 Nov 199I) reported a conflict between women employees and the Stroh's Corporation over the company's use of a "Swedish" bikini team in its beer advertisements.

Io On ABC's family sitcom series "Growing Pains" the adolescent character, Ben Seaver, has a poster of bikini-clad women in his bedroom. The poster is entitled "Island Girls," but all of the women are white.

II For a psychoanalytic discussion of the bomb see Easlea 1983; for a feminist critique of military strategic discourse see Cohn 1990.

I2 My use of Marxist analysis here is superficial; Marx's earlier work on alienation and the transformative power of money might inform my analysis differently, but I have focused only on the first volume of Capital.

I3 Spellman demonstrated the shortcomings of feminist theories that construct sexism and racism as separate and unequal processes of oppression (1988, II7). Pacific Island women activists and academics seem to approach colonialist racism and sexism as coterminal forces. See Souder 1992 and Trask 1989.

I4 NFIP in its turn supports indigenous women's organizing; for example, it cosponsored the conference "Wahine Maoli: Sisters in Solidarity" for native Hawaiian and American Indian women at the University of Hawai'i at Mānoa, 8 March 1992.

I5 Historically, missionaries and colonial agents worked closely, as in the case of Hawai'i; contemporarily, the lines between church and state have been 
blurred, for example, in the legislative and legal battles over abortion in predominantly Catholic Guam, and in Colonel Sitiveni Rabuka's period of "divinelyordained" martial law in Fiji.

I6 The earliest missionaries to the Pacific Islands were Spanish Jesuits who landed on Guam in 1668 (Hempenstall and Rutherford 1984, 98).

I7 The Duff, a vessel enlisted for a British Methodist project, embarked for Tahiti in 1796 , marking the beginning of the second and most extensive wave of missionary efforts in the Pacific (Smith I960, 104).

I8 Missionaries and colonial officials imposed a hierarchy of clothing on native peoples: shoes were denied to many Islanders as they had been to AfricanAmerican slaves; Papuan men were expected to wear short trousers or laplaps but would be penalized, usually by flogging, for donning a shirt (Woolford I974, 9-10).

I9 Recently there has been interest in creating a marine park out of Bikini lagoon and the twenty-one vessels sunk during the 1946 atomic tests (Eliot 1992). Needless to say, the transformation of "a nuclear graveyard" into a tourist site that might generate revenues for Bikinians seems both symbolically and materially bankrupt.

20 For a history of Indonesian policy in West Papua see Budiardjo and Liem 1988.

2I For this reason NFIP has formed alliances with Pacific rim groups in Japan and Canada (Firth 1987).

22 That is, Melanesia (excluding West Papua), Micronesia, and Polynesia (excluding Hawai i and New Zealand). The breakdown is: American Samoa 50,900; Cook Islands 17,800; Federated States of Micronesia II4,800; Fiji 753,000; French Polynesia 205,800; Guam 140,000; Kiribati 75,200; Marshall Islands 52,000; Nauru 9,800; New Caledonia 176,900; Niue 2,200; Northern Marianas 54,000; Palau 15,900; Papua New Guinea 4,056,000; Pitcairn 100; Solomon Islands 337,000; Tokelau I,600; Tonga 97,400; Tuvalu 9,300; Vanuatu 156,500; Wallis and Futuna 14,100; Western Samoa 163,000 (South Pacific Commission 1993).

\section{References}

Aiavao, Tunumafono Apelu

198? Who's Playing Naked Now? Religion and Samoan Culture. Pacific Perspective $\mathrm{I2}(2)$ : 8-10.

Apter, Emily

199I Feminizing the Fetish: Psychoanalysis and Narrative Obsession in Turnof-the-Century France. New York: Cornell University Press.

Ashby, Gene, ed 
1985 Some Things of Value . . Micronesian Customs and Beliefs, by Students of the Community College of Micronesia. Rev ed. Eugene, or \& Kolonia, Pohnpei: Rainy Day Press.

Berger, John

1972 Ways of Seeing. London: BBC \& Penguin Books.

Boyer, Paul

1985 By the Bomb's Early Light: American Thought and Culture at the Dawn of the Atomic Age. New York: Pantheon.

Budiardjo, Carmel, and Liem Soei Liong

1988 West Papua: The Obliteration of a People. Surrey, England: TAPOL, the Indonesian Human Rights Campaign.

Caputi, Jane

199I The Metaphors of Radiation: Or, Why a Beautiful Woman Is Like a Nuclear Power Plant. Women's Studies International Forum I4 (5): 423-442.

Christian, Barbara

1987 The Race for Theory. Gender and Theory: Dialogues on Feminist Criticism, edited by Linda Kauffman, 225-237. New York: Basil Blackwell.

Cohn, Carol

1990 Clean Bombs and Clean Language. Women, Militarism, and War: Essays in History, Politics, and Social Theory, edited by Jean Bethke Elshtain and Sheila Tobias, 33-55. Savage, MD: Rowman \& Littlefield.

Donald, Graeme I985 Things You Didn't Know You Didn't Know. St Leonard's NSW: Unwin.

Drinnon, Richard

1980 Facing West: The Meta-Physics of Indian-Hating and Empire-Building. Minneapolis: University of Minnesota Press.

Eagleton, Terry

1983 Literary Theory: An Introduction. Minneapolis: University of Minnesota Press.

Easlea, Brian

1983 Fathering the Unthinkable: Masculinity, Scientists and the Nuclear Arms Race. Concord, MA: Pluto Press.

Eliot, John L.

1992 In Bikini Lagoon Life Thrives in a Nuclear Graveyard. National Geographic, June, $70-82$.

Firth, Stewart

1987 Nuclear Playground. Honolulu: University of Hawai'i Press.

Freud, Sigmund

196I The Standard Edition of the Complete Psychological Works. London: Hogarth Press. 
Glynn, Prudence

1982 Skin to Skin: Eroticism in Dress. New York: Oxford University Press.

Hempenstall, Peter, and Noel Rutherford

1984 Protest and Dissent in the Colonial Pacific. Apia, Western Samoa: University of the South Pacific.

Hollander, Anne

1990 Swimsuits Illustrated. American Heritage, July-August, 58-68.

IBP, Islands Business Pacific

I988 Tahiti Look. September, 47.

Johnson, Giff

1988 Marshall Islands: Politics in the Marshall Islands. In Micronesian Politics, edited by Ron Crocombe, 67-85. Suva: University of the South Pacific.

I992 Bikinians Accuse US of Reneging. Pacific Magazine, May-June, 49.

Kiste, Robert C.

1974 The Bikinians: A Study in Forced Migration. Menlo Park, CA: Cummings.

\section{Life}

I949 The Trouble with the Bikini. No. 27, 65-66.

Marx, Karl

1962 Capital, vol. I, translated by Eden and Cedar Paul. New York: E. P. Dutton.

MSC, Micronesia Support Committee

1978 Marshall Islands: A Chronology 1944-1978. Honolulu: Micronesia Support Committee.

NWT, New World Times

1990 Testing continues on the Polynesian Islands. Winter, 29.

Owens, Craig

I983 The Discourse of Others: Feminists and Postmodernism. The Anti-Aesthetic: Essays on Postmodern Culture, edited by Hal Foster, 57-82. Seattle: Bay Press.

Rajotte, Freda, and Ron Crocombe 1980 Pacific Tourism as Islanders See It. Suva: University of the South Pacific.

Said, Edward 1978 Orientalism. New York: Vintage Books.

Siwatibau, Suliana, and B. David Williams 1982 A Call to a New Exodus: An Anti-Nuclear Primer for Pacific People. Suva, Fiji: Lotu Pasifika Productions. SJMN, San Jose Mercury News I992 France suspends nuclear testing until 1993. 9 April, I7a. Smith, Bernard 
I960 European Vision and the South Pacific, I768-1850. Oxford: Oxford University Press.

Souder, Laura Marie Torres

1992 Daughters of the Island: Contemporary Chamorro Women Organizers on Guam. 2d ed. Lanham, MD: University Press of America \& University of Guam.

South Pacific Commission

1993 South Pacific Economies Statistical Summary. Noumea: South Pacific Commission.

Spellman, Elizabeth

I988 The Inessential Woman: The Problems of Exclusion in Feminist Thought. Boston: Beacon Press.

Spendlove, Bill

199I On the Beach. Access, 25 September, 5.

Stone, John

1988 Radio Bikini: A Film. CA: Pacific Arts Corps.

Teaiwa, Teresia K.

1992 Microwomen: US Colonialism and Micronesian Women Activists. Pacific History: Papers from the 8th Pacific History Association Conference, edited by Donald H. Rubinstein, I25-I42. Mangilão: University of Guam.

Trask, Haunani-Kay

1989 Fighting the Battle of Double Colonization: The View of an Hawaiian Feminist. Ethnies, Human Rights and Tribal Peoples: Renaissance in the Pacific 4 (8-9-Io): 6I-67.

Weart, Spencer R.

I988 Nuclear Fear: A History of Images. Cambridge, MA: Harvard University Press.

Weera, Meikam

I99I Palau Trusteeship Council Petition. International Work Group for Indigenous Affairs Newsletter, September-October, 28-29.

Woolford, Don

1974 Blacks, Whites, . . . and the Awful Press. New Guinea and Australia, Southeast Asia and the Pacific Islands, January, 4-25.

\section{Abstract}

This paper addresses tourist and militarist notions of the Pacific by discussing the bikini bathing suit and its connection to nuclear testing. The paper begins with an account of nuclear testing on Pacific islands, focusing longest on Bikini Atoll, and ends with a description of the Nuclear Free and Independent Pacific movement. 
The body of the paper is a discussion of the politics of the bikini bathing suit in terms of what it simultaneously reveals and conceals. The bikini reveals the female body in order to depoliticize it and symbolically conceals the bodies of Pacific Islanders in order to depoliticize them. Feminist, psychoanalytic, and Marxist theories are used to argue that the bikini both commodifies a nasty colonial reality and appropriates the female body to divert attention from the indigenous decolonizing efforts. However, while the bikini was created to celebrate nuclear power, s/pacific bodies have survived in spite of nuclear destruction and continue to resist tourist and militarist notions of who they should be. 